\title{
Quality Physical Education Learning through Process Modeling Based on Kinesthetic Perception
}

\author{
Eva Julianti ${ }^{1, *}$, Yusmawati ${ }^{1}$, Heni Widyaningsih ${ }^{1}$, Abd. Halim ${ }^{2}$ \\ ${ }^{1}$ Department of Physical Education, Faculty of Sport Science, Universitas Negeri Jakarta, Indonesia \\ ${ }^{2}$ Department of Primary Teacher Education, Faculty of Teacher Training and Education, Universitas Esa Unggul, Indonesia
}

Received September 22, 2020; Revised January 12, 2021; Accepted January 22, 2021

\begin{abstract}
Cite This Paper in the following Citation Styles
(a): [1] Eva Julianti P, Yusmawati, Heni Widyaningsih, Abd. Halim, "Quality Physical Education Learning through Process Modeling Based on Kinesthetic Perception," International Journal of Human Movement and Sports Sciences, Vol. 9, No. 1, pp. 89-96, 2021. DOI: 10.13189/saj.2021.090112.
\end{abstract}

(b): Eva Julianti P, Yusmawati, Heni Widyaningsih, Abd. Halim (2021). Quality Physical Education Learning through Process Modeling Based on Kinesthetic Perception. International Journal of Human Movement and Sports Sciences, 9(1), 89-96. DOI: 10.13189/saj.2021.090112.

Copyright $\odot 2021$ by authors, all rights reserved. Authors agree that this article remains permanently open access under the terms of the Creative Commons Attribution License 4.0 International License

\begin{abstract}
The aim of this study is to propose a practical, theory-based framework that can be applied in analyzing the modeling of quality physical education based on kinesthetic perception as a socio-technical entity, and in identifying potential improvements. Physical education learning in elementary schools is one of the important stages for optimizing the development of a child's fundamental movement, stimulating motor abilities and physical activities that stimulate intelligence optimization. However, kinesthetic perception is the feeling of muscle that directs the movement correctly, without using the eyes. Method of this research used Modeling Process and Mingers' sequential type multi-method research design. Since there is no single model, this study consolidated a hybrid model (motor learning Model, sport education model, Tactical Games Approach model and VARK learning model). Research process (Constructing thematic questionnaires, web-based data collecting and analyzing data) and this article presents the results of the first stage i.e. theory adaptation as resilient arguments about the need to develop a quality physical education learning model based on kinesthetic perceptions for elementary school students.
\end{abstract}

Keywords Learning Model, Physical Activity, Kinesthetic Perception, Cognition, Intelligence

\section{Introduction}

The United Nations Educational, Scientific and Cultural
Organization (UNESCO, 2017) stated that the benefits of quality physical education can be achieved by qualified teachers; inclusive, flexible and interactive classes that motivate all children to push their boundaries regardless of their physical capacity, background, religion or gender.

Meanwhile, according to the National Association for Sport and Physical Education (NASPE), quality physical education is built on four foundations, namely: 1) Opportunities for learning, where students must receive physical education (based on a curriculum of 100-135 minutes each week), get a position that is equal to other subjects, and use the environment, and safe equipment for students; 2) Meaningful Content. Following the national curriculum; Instruction in a variety of motor skills are designed to enhance the physical, mental, and social/emotional development of each child; education and fitness assessments to help children understand, improve and/or maintain physical well-being; Development of cognitive concepts about motor skills and fitness; opportunities to improve social and cooperative skills, and motivate physical activity sufficient for the present and throughout life; 3)Appropriate instructions, namely: Inclusion for all students; Maximum opportunity to practice for classroom activities; Well-designed lessons that facilitate student learning; Out-of-school assignments that support learning and practice; Physical activity is not designated as or held as punishment; Regular assessments to monitor and reinforce student learning; 4)Student and program assessment. Assessment is an important, continuing part of the physical education program 
containing formative and summative assessment of students' progress. Student assessment aligned with state/national physical education standards physical education curriculum, assessment of program elements that support quality physical education and stakeholders regularly evaluate the total effectiveness of the physical education program.

Quality physical education provides learning opportunities, appropriate teaching, meaningful and challenging content, and student assessment, curriculum and learning. In addition, quality physical education increases mental alertness, academic achievement, and readiness, increases students' self-confidence, concentration and communication skills so as to make them active, healthy, responsible and knowledgeable and enthusiasm for learning. However, UNESCO has not mentioned what quality physical education teachers are and how to create quality physical education teachers.

Javier Vernandez [1] then answers this absence, since there is no perfect model to prove quality physical education and no single model that fits all contexts of physical education, with a combination of model-based practices. In this article, we highlight interactive classes that motivate all children to push their boundaries regardless of their physical capacity, background, religion or gender.

Physical education classes that are interactive through pedagogical methods and the special interactive nature of the relationship between teachers and students (in an educational setting in a sports gym) should aim to strengthen individual character (moral values, beliefs, motivation and interests such as motor skills or sports skills) to develop an active lifestyle not only at school, but throughout his life. If processes are presented appropriately, based on pedagogical principles, then basic motor skills (i.e. running, jumping, jumping, or catching) can be a means of achieving social and moral development. The variety of activities, forms and methods of delivery, and the breadth of context should only enhance the educational process and help students have an active lifestyle throughout their lives.

Interactive learning to motivate students can be based on the theory of multiple intelligences by Howard Gardner [2], which has helped in the field of education to improve students' vision while theory supports the emergence of new ways to optimize their learning. The nine compound intelligences are: 1) Verbal-Linguistic Intelligence; 2) Mathematical-Logical Intelligence; 3) Music Intelligence; 4) Visual-Spatial Intelligence; 5) Body Kinesthetic Intelligence; 6) Interpersonal Intelligence; 7) Intrapersonal Intelligence; 8)Naturalist Intelligence; and 9) Existential Intelligence.

Based on its characteristics, physical education has advantage in the development of multiple intelligences, particularly in Visual-Spatial Intelligence and Body Kinesthetic Intelligence. This paper then aims to develop a physical education learning model based on kinesthetic intelligence, mainly kinesthetic perception. The body's kinesthetic intelligence is the ability to manipulate objects and use various physical skills. This intelligence also involves a sense of timing and the perfection of skill through the association of thought (body and mind). Athletes, dancers, surgeons, and craftsmen demonstrate a well-developed kinesthetic intelligence of the body.

However, Kinesthetic Perception, also referred to as kinesthesia, is the perception of body movements. This involves the ability to detect changes in body position and movement without relying on information from the five senses.

\subsection{The Aim}

The aim of the research is to develop a quality physical education learning model based on kinesthetic perception.

\subsection{Tasks}

1. To find out physical activities that can improve kinesthetic intelligence;

2. To integrate physical activities based on kinesthetic perception into physical education learning;

3. To develop a physical education learning model based on kinesthetic perception that can improve Body-kinesthetic (and Visual-spatial) intelligences.

\section{Methods}

Research and Development (R\&D) Method is a process of developing a new product or an existing product. According to Borg \& Gall [3], research and development method is a method used to produce a certain product, and test the effectiveness of the product. Educational R\&D is a process of developing and validating educational products, an effective product and not to test theory [4].

This research is part of the research and development phase conducted by researchers. The first stage is literature studied to synthesize existing kinesthetic perception-based learning theories and principles. The next stage is a survey to collect information on kinesthetic perception-based physical education learning in primary schools. Respondents of this study were primary school physical education teachers in DKI Jakarta.

Literature study data were analyzed using a normative approach, while survey data were analyzed using descriptive analysis. Through these stages we have a theoretical and empirical basis in developing a kinesthetic perception-based physical education learning model.

The instrument used for the survey was a questionnaire developed by researchers. Since there is no single quality physical education model that can represent all the components needed, the researchers conducted an evaluation of the physical education learning process 
using consolidate models method and process modeling method as a first stage to obtain adequate information for later use in developing a physical education learning based on Kinesthetic Perception model. Process modeling was one of the main research lines of this research.

Consolidate models is a process of combining single models into one fulfilled model. The individual items from each model are retained in the consolidated model. However, process modeling is commonly used for these purposes. It is an important supportive activity to increase understanding of the target domain by producing models that aim to describe, prescribe or explain the socio-technical system.

\subsection{Consolidated Models}

\subsubsection{The Motor Learning Model}

This model is in accordance with the motor learning theory by Schmidt [4]. Motor learning theory (1988) assumes that the brain constructs a forward model that predicts the sensory consequences of motor commands, and an inverted model that produces a successful command of movement goals that emphasizes the interactive role of three elements: 1) the goal and task conditions; 2) environmental situation, and 3) capability and intention. The previous theory states that motor learning will be successful if there is differentiation in the complexity of the task and on changes to obtain it, both of which must always be increased and modified gradually.

For educators, it becomes a challenge to develop and intervene through an interactive learning approach. Better intellectual and emotional development in high school students requires an interactive learning process.

\subsubsection{A Sport Education Model}

According to Daryl Siedentop [6], sport education is a curriculum and instruction model designed to provide authentic, educationally rich sport experiences for girls and boys in the context of school physical education. School sport providing a wide range of sporting activities, where emphasis is on participation, competition and the score may also contribute to learning in a social context. Characteristic features of this model include: lots of formal competition aimed at winning (winning "at all cost" syndrome); record-oriented contents; extended (longer than usual) teaching units; combination of teaching and training methods, styles (with an emphasis on training and instruction rather than on pedagogical aims); sport skills practicing over health and physical activity education; the most talented in the scope of interests, weaker individuals often left aside; contents of the lessons change with the sport seasons; usually classes are well-organized (routine).

\subsubsection{The Tactical Games Approach Model}

Tactical awareness in a game first before other skills can be developed. Using students' interests, knowledge, and stages of development to create appropriate versions of the game and practical assignments generate is an explanation of the game. The game can be divided into: invasion games, net / wall games, field / run score games and target games. The Teaching Game for Understanding (TGfU) Model of 9 Games Kirk \& MacPhail [7] focuses on tactical awareness, which is believed to be necessary for making critical decisions in the complexity of the game being played. The course content should be designed in a way that gives students the opportunity to develop confidence and competence in skills and strategies. First, teachers must focus on increasing strength. Then the teacher can begin to provide instructions (limited to the instructions needed - for example, specific movement instructions or tactical solutions). The next stage in the Tactical Gaming Approach involves modification of the equipment or educational context, followed by an appropriately designed developmental step. Finally, if there is no progress or continuous errors, the teacher provides feedback (Michal Bronikowski[8]).

\subsubsection{VARK Learning Style}

There are many different ways of categorizing learning styles, but Neil Fleming's Visual Aural/Auditory, $\mathrm{Read} /$ Write, Kinesthetic Learners (VARK) model is one of the most popular. The acronym "VARK" is used to describe four modalities of student learning that were described in a 1992 study by Neil D. Fleming and Coleen E. Mills [9]. They introduced an inventory that was designed to help students and others learn more about their individual learning preferences. According to the VARK model, learners are identified by whether they have a preference for: Visual learning (pictures, movies, diagrams); Auditory learning (music, discussion, lectures); Reading and writing (making lists, reading textbooks, taking notes); Kinesthetic learning (movement, experiments, hands-on activities)

\subsection{Process Modeling Steps}

There are numerous studies published that focus on different elements that are related to process modeling. This Research follows on the Activity Theory and Process Modeling literature as well as Activity Theory and Activity-Driven (AD) approaches to ISD to give readers a glimpse of the philosophy and practical principles of the AD approach, and justify choosing a framework. Activity Theory (AT) was originally a socio-cultural theory to understand cooperative human activities that have goals and socio-technical systems (activities and information systems). (Hedegaard, et al.[10])

Process Modeling Work Activity (PMWA) is considered appropriate to explain kinesthetic perceptions in learning as an information system process and activities as a result of the process of information received. 


\subsection{Research Objective and Research Design}

The aim of this study is to propose a practical, theory-based framework that can be applied in analyzing the modeling of quality physical education-based on kinesthetic perception as a socio-technical entity, and in identifying potential improvements.

To improve the modeling process in the idea of quality physical education, we must first understand modeling work and its elements, identify the problem, and seek to understand the reasons behind the problem.

The research design follows an approach consistent with the sequential type multimethod research design (Mingers [11], Mingers and Brocklesby [12]). The research design includes three main research activities i.e.: Constructing thematic questionnaires, web-based data collecting and analyzing data.

With the limitations of research, the thematic questionnaire uses a digital form, and then data collection and analysis are carried out to produce a need analysis study of quality physical education models based on kinesthetic perception.

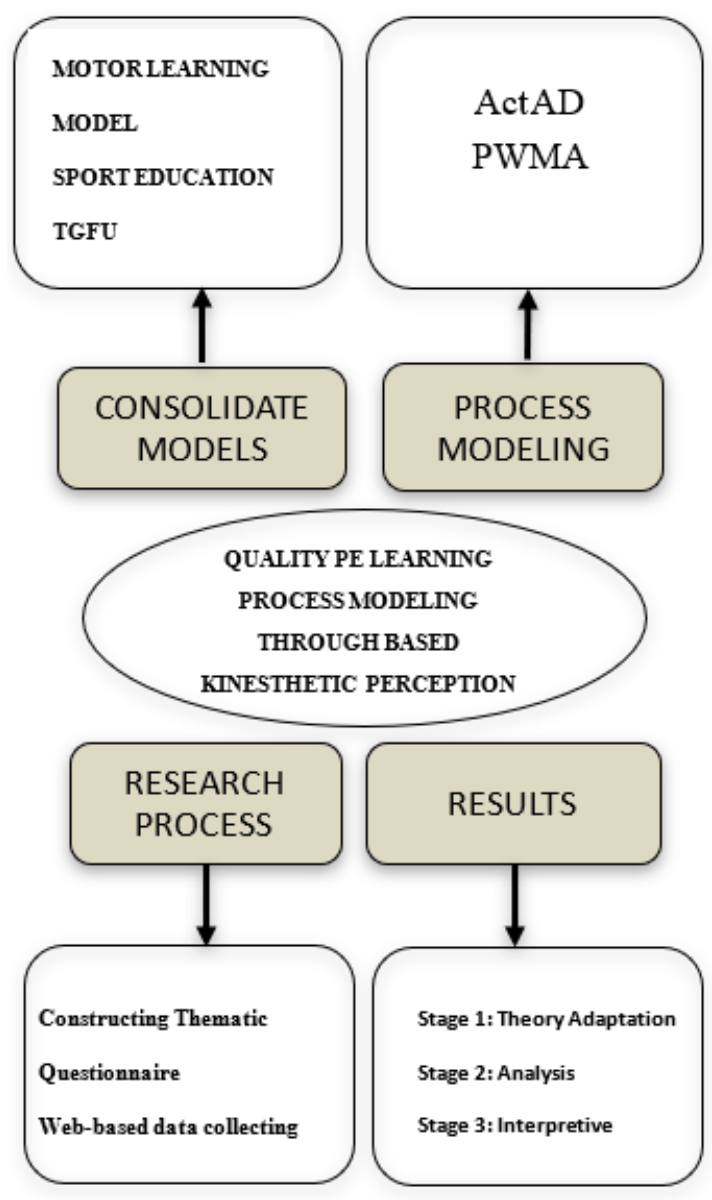

Figure 1. Research Design

\section{Results and Discussion}

The results of this study are based on three stages of process modeling. The first stage is theory adaptation; construct the thematic questionnaires that were derived from Process Modeling Work Activity (PMWA). This work activity (Engestrom [10]) must start investigation when the information system is developed. The Act AD (Activity Driven) framework where the Work Activity (WA) as a systemic entity, includes: actor; object; outcome; means of work; means of cooperation, communication and coordination; collective actor; process, input and output. Table 1 summarizes some major elements of PMWA (adapted from Luukkonen and Mykkanen [11]).

Thematic questionnaires collected are based on process modeling (motor learning, sports education, TGFU and VAK Learning Style). All questions and sub questions are in a structured (closed) form using Likert scale. The theme in the questionnaire related to motor learning is about three stages in motor learning: a cognitive phase, an associative phase, and an autonomous phase. Where the movement changes from the previous are slow, inconsistent, and inefficient, and large parts of the movement are controlled consciously.

Table 1. The major elements of PMWA

\begin{tabular}{|c|c|}
\hline Element & Elements in WA Process Modeling \\
\hline Actor & $\begin{array}{c}\text { Participants in modeling; students, physical } \\
\text { educators }\end{array}$ \\
\hline Object & Target processes (PE classroom) \\
\hline Outcome & $\begin{array}{l}\text { Products that represent the increased } \\
\text { knowledge and facts of the target processes } \\
\text { (Learning environment, classroom } \\
\text { management, PE learning outcomes) }\end{array}$ \\
\hline Means of work & $\begin{array}{l}\text { Means by which the modeling is conducted, } \\
\text { both artifacts and mental means }\end{array}$ \\
\hline $\begin{array}{c}\text { Means of } \\
\text { cooperation, } \\
\text { communication and } \\
\text { coordination }\end{array}$ & $\begin{array}{c}\text { The communication and coordination of all } \\
\text { participants in the modeling }\end{array}$ \\
\hline Collective actor & $\begin{array}{l}\text { Individual actors whose cooperative efforts } \\
\text { are needed }\end{array}$ \\
\hline Input & $\begin{array}{l}\text { The inputs which have been formulated in } \\
\text { the preceding activities and used in the } \\
\text { process modeling WA }\end{array}$ \\
\hline Process & Process of modeling \\
\hline Output & $\begin{array}{c}\text { The deliverables of the process modeling, } \\
\text { reused by others }\end{array}$ \\
\hline
\end{tabular}

TGFU is an inquiry approach to teaching games where the games are taught before skill refinement. There are four basic types of play: invasion / territory, net / wall, strike / fielding and target.

What can be formulated from the sports education model is that it intends to provide children and adolescents with a more authentic and enjoyable sports experience than is usually seen in previous physical education classes; Students participate in as team members; taking an active role in their own sporting experience by living out the varied and realistic roles we see in authentic sports settings; develops friendships 
through team uniforms, names, and cheers as they work together to learn and develop tactical skills and play. The three main goals that guide program development in Sport Education Model (SEM) are for students to become competent, mobile, and enthusiastic individuals.

While VAK learning styles use three main sensory receivers: Visual, Auditory, and Kinesthetic (movement) to determine the dominant learning style. VAK is also known as VAKT (Visual, Auditory, Kinesthetic, \& Tactile). It is based on modality - the channel in which the individual expresses and consists of a combination of perception and memory.

Since there is no single model that can provide a picture of quality physical education, there are opportunities for researchers, observers of physical education, teachers and policy makers to create a model that combines the various goodness of physical education learning models, a hybrid model of physical education based. The kinesthetic perspective benefits students by further increasing self-confidence, because without depending on the five senses, especially the eyes, they can perform motoric skill. In addition, students will have balanced and precise movements, as they use their perceptions more than five eye senses. Students will get used to and have extraordinary motoric skills and are useful in their daily activities throughout their lifespan. Of the three stages in this research design (Constructing thematic questionnaires, web-based data collecting and analyzing data), we discuss the result of the first stage i.e. Constructing thematic questionnaires as resilient arguments about the need to develop a quality physical education learning model based on kinesthetic perceptions for elementary school students.

Main concepts of the modeling process are then organized into open and closed questions. The predefined answer choices for multiple choice questions identified in the process modeling literature correspond to the major elements in PWMA.

The questions were deeply tested by experts in psychology, motor learning, physical education, teachers, and linguists and modified according to expert input. Using Indonesian language is adjusted to understanding. The original language of the questionnaire is Indonesian, which can improve the accuracy and understanding of the respondents. This article does not present a whole questionnaire and theme, and will be shown in another attachment.

Stage 2: analyze can be considered as the goal setting for the learning model. We focus on the target audience i.e., students. It is also here that the model matches the level of skill and intelligence of student/participant. This aims to ensure that what they already learned won't be replicated, and that the learning focus will instead be on topics and lessons that students have yet to explore and learn. In this stage, we differentiate between what the students known and what they should know after finishing the lesson.

The analysis stage results answered the following issues and questions:

The background of the students/participants i.e. personal and educational information such as age, previous experiences and interests; The students need to accomplish learning, learner's needs, learning target, educational goals, past knowledge levels, experiences, ages, interests, learning style of the learners, the Requirements of skills, intelligence, attitude and physical/psychological action-reaction; the desired learning outcomes in terms of knowledge, skills, attitudes, behavior; popular methods being used around the subject and taking a look at what needs to be developed and improved; review of existing instructional strategies employed; target objectives of the project; instructional goals of the project; various options available with respect to learning environment.; the most conducive learning environment; a combination offline/live or online learning; restrictive factors to the overall goal.

Table 2. Stage 2 of Process Modeling Result

\begin{tabular}{|c|c|}
\hline Actor & Physical Education Teachers and Students \\
\hline Object & Physical Education Lesson \\
\hline Outcome & $\begin{array}{l}\text { Quality Physical Education learning based } \\
\text { on kinesthetic perception }\end{array}$ \\
\hline Means of work & $\begin{array}{l}\text { Physical Education Facilities, props and } \\
\text { equipment needed in the learning model } \\
\text { based on kinesthetic perception }\end{array}$ \\
\hline $\begin{array}{l}\text { Means of } \\
\text { cooperation, } \\
\text { communication and } \\
\text { coordination }\end{array}$ & $\begin{array}{c}\text { The Teacher-Students and } \\
\text { Student-Student communication and } \\
\text { coordination during Physical Education } \\
\text { Lesson }\end{array}$ \\
\hline Collective actor & $\begin{array}{l}\text { Other Physical Education teacher or } \\
\text { proficient students }\end{array}$ \\
\hline Input & $\begin{array}{l}\text { Physical education activities based on } \\
\text { kinesthetic perception formulated in the } \\
\text { first stages from experts in the process } \\
\text { modeling }\end{array}$ \\
\hline Process & $\begin{array}{l}\text { Process modeling activities based } \\
\text { kinesthetic perception }\end{array}$ \\
\hline Output & $\begin{array}{l}\text { The result of process modeling, a physical } \\
\text { education learning model based } \\
\text { kinesthetic perception that is easy to reuse } \\
\text { by other teachers }\end{array}$ \\
\hline
\end{tabular}

Finally, at the third stage, we interpreted the analysis results by outlining a quality physical education learning based on kinesthetic perception, which can be seen in the diagram below: 


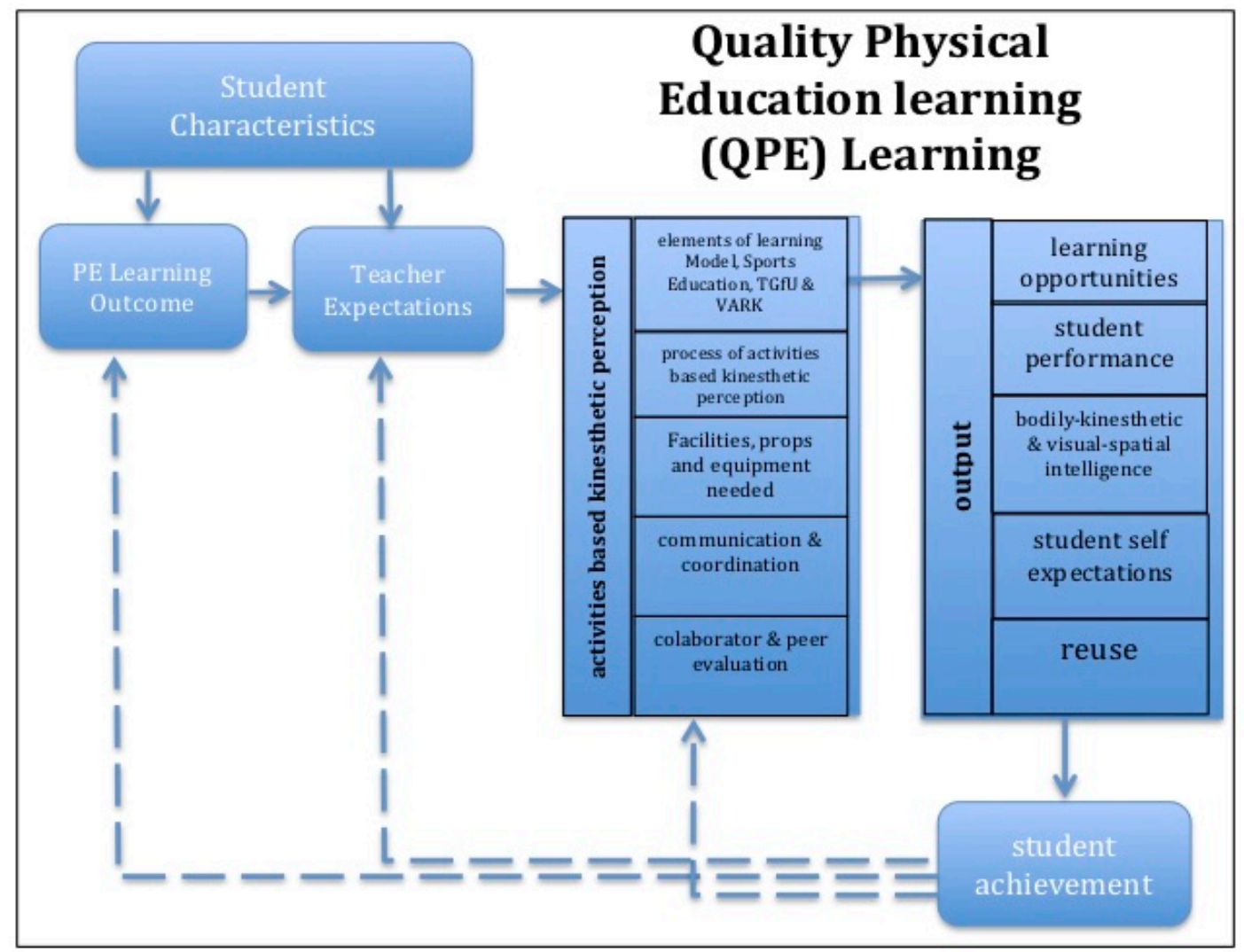

\begin{tabular}{|l|l|}
\hline & $\begin{array}{l}\text { The main elements of Motor Learning Model are three stages of learning motor skills: a cognitive phase, } \\
\text { an associative phase, and an autonomous phase. Earlier, movements are slow, inconsistent, and inefficient, } \\
\text { and large parts of the movement are controlled consciously. Motor learning is a complex process } \\
\text { occurring in the brain in response to practice or experience of a certain skill resulting in changes in the } \\
\text { central nervous system. It allows for the production of a new motor skill. } \\
\text { Kinesthetic perception focusing for this element on physical activities that need kinesthetic perception and } \\
\text { visual-spatial movement. }\end{array}$ \\
$\begin{array}{l}\text { The main elements of Sports Education is sports program that enhance students to become competent, } \\
\text { literate, and enthusiastic players by designed learning experiences that facilitate students learning in } \\
\text { realistic settings. } \\
\text { Kinesthetic perception focusing for this element on experiencing sports game that needs kinesthetic } \\
\text { perception and visual-spatial movement. }\end{array}$ \\
$\begin{array}{l}\text { The main element of TGfU is the teacher conveying why to do, and how to do a game before students } \\
\text { make decisions and play games. The result of a combination of knowing the objectives and how to play } \\
\text { will result in performance and understanding of learning objectives through play. Furthermore, the task of } \\
\text { the physical education teacher is to increase student skills to next level. } \\
\text { Kinesthetic perception focusing for this element on experiencing games in learning that needs kinesthetic } \\
\text { perception and visual-spatial movement. }\end{array}$ \\
$\begin{array}{l}\text { The main elements of VARK Learner model are identifying students as visual, auditory, reading/writing, } \\
\text { kinesthetic, learners, and aligning overall curriculum with these learning styles. } \\
\text { Kinesthetic perception focusing for this element on blending learning activities that need kinesthetic } \\
\text { perception and visual-spatial movement. }\end{array}$ \\
\hline
\end{tabular}

Figure 2. Quality Physical Education Learning Process Modeling based on Kinesthetic Perception

Thematic questionnaires are collected based on process modeling. Based on the information and characteristics summarized in this hybridization model, 15 themes were obtained with a total of 115 questions related to them (motor learning, sports education, TGFU and VAK Learning Style). 


\section{Motor Learning}

The questionnaire given to the teacher was designed to determine the application of motor learning in physical education activities based on kinesthetic perception. This is none other than to develop fundamental motor skill in any appropriate stages.

Table 3. Respondents respond of thematic questionaire related to motor learning model

\begin{tabular}{|c|c|c|c|c|c|}
\hline \multirow{2}{*}{ Themes } & Sample & \multicolumn{3}{|c|}{ Answer Percentage (\%) } \\
\cline { 2 - 6 } & $\mathrm{n}$ & SA & A & NA & $\begin{array}{c}\text { D } \\
\text { A }\end{array}$ \\
\hline Motor Learning Stages & 25 & 20 & 72 & 8 & \\
\hline $\begin{array}{c}\text { Skill acquisition: } \\
\text { consistency, flexibility } \\
\text { and efficiency }\end{array}$ & 25 & 20 & 80 & & \\
\hline Measurement of learning & 25 & 28 & 68 & 4 & \\
\hline
\end{tabular}

The results of the questionnaire for the motor learning show that learning should be designed to enhance motor learning activities, since in primary school, all lessons use a thematic approach. Most respondents agree that motor learning stages, skill acquisition (consistency, flexibility and efficiency in movement) and also measurement of motor learning should be focused on learning.

\section{Sports Education}

The questionnaire given to the teacher was designed to determine the application of existing sports education model in physical education activities based on kinesthetic perception. This is none other than to give student real experience and fun in sports game.

Table 4. Respondents respond of thematic questionaire related to sports education model

\begin{tabular}{|c|c|c|c|c|c|}
\hline \multirow{2}{*}{ Themes } & Sample & \multicolumn{4}{|c|}{ Answer Percentage } \\
\cline { 2 - 6 } & $\mathrm{n}$ & SA & A & NA & DA \\
\hline Promote Skill & 25 & 60 & 32 & 4 & 4 \\
\hline Sports team player & 25 & 40 & 60 & & \\
\hline Competition & 25 & 52 & 40 & 8 & \\
\hline Fun & 25 & 72 & 28 & & \\
\hline Involvement & 25 & 40 & 52 & 4 & 4 \\
\hline
\end{tabular}

The results of the questionnaire for the sports education show that physical education learning should be designed to enhance sport game activities, and students will have Total Sport Experiences (TSE). Most respondents strongly agree that physical education activities should have any activities to promote skill, give student experience as a player in a sports team, and create real competition in miniature situation. All activities give student fun and involve all students in a game.

\section{Teaching Game for Understanding (TGfU)}

The questionnaire given to the teacher was designed to determine the application of existing TGfU model in physical education activities based on kinesthetic perception. This is none other than to give students fun in learning that we believe will give them more understanding about the Physical education lesson.

Table 5. Respondents respond of thematic questionaire related to TGfU model

\begin{tabular}{|c|c|c|c|c|c|}
\hline \multirow{2}{*}{ Themes } & Sample & \multicolumn{4}{|c|}{ Answer Percentage } \\
\cline { 2 - 6 } & $\mathrm{n}$ & SA & A & N & DA \\
\hline Game & 25 & 60 & 40 & & \\
\hline Game Appreciation & 25 & 36 & 64 & & \\
\hline Tactical Awareness & 25 & 20 & 72 & 4 & 4 \\
\hline $\begin{array}{c}\text { Appropriate } \\
\text { Performance }\end{array}$ & 25 & 40 & 56 & 4 & \\
\hline Skill Execution & 25 & 32 & 68 & & \\
\hline Performance & 25 & 40 & 52 & 8 & \\
\hline
\end{tabular}

The results of the questionnaire for the TGfU show that physical education learning should design more fun activities, and students will appreciate the lesson. Most respondents agree that physical education activities should have any activities that include Game, Game Appreciation, Tactical Awareness, Appropriate Performance, Skill Execution and more chance to show their Performance.

\section{Visual, Audio, Read and Kinesthetic (VARK) learner}

The questionnaire given to the teacher was designed to determine the application of existing VARK model in physical education activities based on kinesthetic perception. This is none other than to give students with learning experience that pairs to their learning style.

Table 6. Respondents respond of thematic questionaire related to VARK learning model

\begin{tabular}{|c|c|c|c|c|c|}
\hline \multirow{2}{*}{ Themes } & Sample & \multicolumn{5}{|c|}{ Answer Percentage } \\
\cline { 2 - 6 } & $\mathrm{n}$ & SA & A & NA & TS \\
\hline Visual & 25 & 72 & 28 & & \\
\hline Audio & 25 & 60 & 40 & & \\
\hline Reading & 25 & 40 & 52 & 8 & \\
\hline Kinesthetic & 25 & 84 & 16 & & \\
\hline
\end{tabular}

The results of the questionnaire for the VARK show that physical education learning should design with personal approach, using understanding of student's different learning style.

\section{Conclusions}

The framework presented in this article gives a framework to analyze process modeling to produce a quality physical education model based on kinesthetic perception. This framework is not ready to be used as such in physical education, but must go through the next 
stage, gathering as much data as possible, refining the model, testing and finding problems, fixing it and then interpreting it according to the conditions.

Conclusively using this model, students will learn movement from Physical Education through real intuition when they start the learning, and not through the verbal description of things (J.A. Comenius [14]).

Based on the existing model, the researcher offers physical education learning based on kinesthetic perception model including 1) Element model of four existing models (motor learning, sports education, TGfU and VARK); 2) process activities based on Kinesthetic perception; 3) facilities; 4) communication and collaboration; 5) collaborate and peer evaluation. This finding certainly needs to be investigated further through a series of subsequent research and development.

\section{Acknowledgments}

We are very grateful to experts for their appropriate and constructive suggestions to improve this article.

\section{REFERENCES}

[1] Javier Fernandez-Rio. Quality Physical Education through Models-Based Practice, Conference: 8th International Scientific Conference on Kinesiology At: Opatija (Croatia). 2017.

[2] Gardner, Howard. Frames of mind: The theory of multiple intelligences. UK: Hachette. 2011

[3] M.D. Borg \& Gall, Joyce P. Educational Research: An Introduction, 7th Edition. Utah: Pearson. 2003.

[4] Richard A. Schmidt and Tim Lee. Motor Learning and Performance 6th Edition with Web Study Guide-Loose-Leaf
Edition: From Principles to Application $6^{\text {th }}$ Edition. Philadelphia: Human Kinetics Publishers. 2019.

[5] Daryl Siedentop. What is Sport Education and How Does it Work? Journal of Physical Education, Recreation \& Dance. 1998. 69:4, 18-20. DOI: 10.1080/07303084.1998.10605528

[6] Kirk D, MacPhail A. Teaching games for understanding and situated learning: Rethinking the Bunker-Thorpe model. Journal of teaching in Physical Education. 2002 Jan 1; 21(2):177-92.

[7] Michał Bronikowski. Physical education teaching and learning. Academia Wychowania Fizycznego im. Eugeniusza Piaseckiego. 2010.

[8] Neil D. Fleming and Colleen Mills. Not Another Inventory, Rather a Catalyst for Reflection From To Improve the Academy, Vol. 11. NZ: Lincoln University. 1992: 137.

[9] Hedegaard M, Chaiklin S, Jensen UJ. Activity theory and social practice: An introduction. Activity theory and social practice. 1999:12-30.

[10] John Mingers. Combining IS Research Methods: Towards a Pluralist Methodology. Information Systems Research, Vol. 12, No. 3. 2001: 240-259

[11] Mingers, J. and Brocklesby, J. Multimethodology: towards a framework for mixing methodologies', Omega. 25(5). 1997:489-509

[12] Yrjo Engestrom. Activity theory as a framework for analyzing and redesigning work, Ergonomics, 43:7, 2000: 960-974. DOI: 10.1080/001401300409143

[13] Luukkonen, Irmeli and Juha Mykkanen. Analyzing Process Modelling as Work Activity, Conference Paper, Research Gate.2012.

[14] Björn Norlin. Comenius, moral and pious education, and the why, when and how of school discipline, History of Education, 49:3, 2000:287-312, DOI: 10.1080/0046760X.2 020.1739759

[15] Kostiantyn Prontenko, et al. Formation of Readiness of Future Physical Culture Teachers for Professional Activity, Universal Journal of Educational Research 7(9): 1860-1868, 2019, DOI: 10.13189/ujer.2019.070903 